\title{
THE NATIONAL INCOME
}

\author{
OF \\ BECHUANALAND \\ PROTECTORATE 1955*
}

\section{Introduction.}

The problems of economic development in Africa, south of the Sahara, excluding the Union of South Africa, may in general be regarded as homogeneous. Most of the inhabitants of this continent are Bantu, whose productivity and standard of living in terms of Western civilization are fairly low. This low productivity may inter alia be ascribed to the fact that the economic activities in the relevant national economies are characterized by the desire to supply only the minimum requirements of existence.

As a result of this production pattern, which is closely interwoven with traditional customs and attitudes to life, the development from a subsistence economy to an exchange economy which has so far taken place on this continent, may chiefly be ascribed to the contact of migratory

* Op uitnodiging van die International Association for Research on Income and Wealth het die skrywer die Afrikakonferensie gedurende Januarie vanjaar in Addis Ababa bygewoon. Dit het onder die beskerming van die Verenigde Volke se Ekonomiese Kommissie vir Afrika plaasgevind en is deur 'n dertigtal persone, hoofsaaklik uit Afrika, maar ook uit die V.S.A., V.K., Frankryk en Portugal, bygewoon. labourers with an exchange economy, but especially to the role of foreign capital and - enterprise. E. R. Black, president of the World Bank, writes as follows in this connection: "Development initiative in Africa has always come and still comes, almost exclusively from a small number of Europeans, Indian and Levantine entrepreneurs... It is safe to say that African development will lag behind that of other continents so long as modern economic life remains the business of the very few. Without domestic savings invested in pro. ductive development projects there will never be enough productive labour, either to exploit more than a fraction of Africa's great potential." ")

As is proved by a large number of recent studies concerning the economic and social development of the various coun. tries in Africa, interest in this continent is increasing. The relevant economic literature may be divided into: (a) extensive studies of the nature of the economic problems in Africa; (b) more specific surveys of the various territories, and (c) publications in connection with specific territories in which national accounts are taken as a basis for economic analysis.

1) E. R. Black: "How the World Bank is helping to Develop Africa," Optima, September 1958. 
The aim and extent of this study is to determine the geographical and national income of Bechuanaland Protectorate with in the framework of the economic structure of the country.

\section{The economic structure of the country.}

a. The country and its population.

Bechuanaland Protectorate is the biggest of the three British Protectorates in Southern Africa. It has never been completely surveyed, but the area is estimated at 276,667 square miles, which is about the same as the total of the Transvaal, Orange Free State, Natal and Basutoland.

The main characteristic of the area is the lack of water - surface as well as underground. The only permanent water supplies above ground are found in the Okovango, Chobe, and Zambesi rivers in the north. The rainfall of the territory is between 10 and 27 inches per year, which is sufficient for the flora.

The mineral resources of the territory are underdeveloped. Gold, silver and kyanite have been mined for many years in the Tati district, and asbestos is present in various places, e.g. in the Tati district and in the vicinity of Serowe, with the most important deposit at Mosheneng, about 40 miles west of Lobatsi in the Ngwaketse reserve, where it is being mined. In addition, recent geographical surveys indicate the possibility of an extension of the Waterberg coal deposits to the Kgatla reserve and further north in the vicinity of Palapye in the Ngwato reserve. Apart from these, deposits of fluorite, galena, hidromuscovite, iron ore, and copper have been discovered in the eastern part of the Ngwato reserve. A deposit of high-grade iron ore has been discovered near Mahalapye in the same region.

The nature and composition of the population in this territory are totally different from those in the other High Commission territories. In contrast to Basutuland where there is no alienation of land, and where the white population consists solely of traders, missionaries, and civil servants, with a few professional people in a town like Maseru, the Europeans in Bechuanaland own a small portion of the total area of the territory (except for the Chanzi settlement in the west the European blocks are all situated on the eastern horder of the territory). In Swaziland white settlement has taken place on a larger scale than in Bechuanaland, and areas which have been reserved for the Bantu in Swaziland, alternate with white areas, so that Europeans and non-Europeans live next to one another in their own areas.

The population of Bechuanaland is estimated to be as follows for $1955:{ }^{1}$ ) Bantu 372,276, Europeans 2,659, Asiatics 116 and Coloureds 1,109 .

This territory which consists of crownlands, European blocks and Bantu reserves, is divided into 12 districts for administrative purposes. Each district has its own administrative office and officials. Mafeking, in the Union of South Africa, is the seat of the government. The Resident Com. missioner, who is the chief administrative officer under the High Commissioner for Basutoland, Bechuanaland Protectorate and Swaziland, has his office there.

1) The latest published census figures available are for 1946 . 
With regard to communications it must be pointed out that the only railway line through the territory runs from Ramatla. bama, in the south, to Remaquababe, in the north - a distance of 394 miles. In 1955 it was owned by Rhodesia Railways Ltd. but managed by the South African Railways and Harbours. With the exception of the short tarred roads in Lobatsi and Francistown, and a relatively short distance which has been gravelled, all the roads consist of earth and sand. The only main road through the territory from Mafeking to the Rhodesias follows the same route as the railway, and is, together with the other secondary roads in the immediate vicinity (about 50 miles east and west) of the main road, the only easily passable road. The most important population cen. tres adjoining the railway line are connected to the South African and South Rhodesian telegraphic systems.

Of all the forms of economic activity in the area the subsistence economy is still the most important. It requires a system in which the profit motive plays a very small part and wealth is accumulated almost exclusively in the form of cattle.

In order to ascertain the living stan. dard of the population it is necessary to calculate the value of national production or national income.

b. The composition of the geographical and the total national income of the territory.

(i) Problems in connection with the calculation of the national income of the territory.

(a) Importance of the subsistence sector.

An attempt at analysing the structure and problems of a primitive community such as Bechuanaland in the light of modern economic concepts, reveals fundamental problems of calculation. National in. come and related concepts were primarily developed for the analysis of economic relations in modern exchange economies. It is, however, uncertain whether the existing methods of analysis may conveniently be applied to material other than that for which they have been developed. P. Deane says, for example: "It is not clear what light, if any, is thrown on subsistence economies by a science which seems to regard the use of money and specialisation of labour as axiomatic. The jargon of the market place seems remote, on the face of it, from the problems of an African village where most individuals spend the greater part of their lives in satisfying their own or their families' needs and desires, and where money and trade play a subordinate role in motivating productive activity".

And Prest and Stewart remark that: "tables which show the breakdown of production or consumption in precisely the ways in which they are usually broken down in advanced countries, may be completely irrelevant ... It is the pre-industrial revolution economics of Adam Smith and not the economics of the modern American college text-book which is the relevant standard".')

In general only those goods and services which have a definite price in the

1) P. Deane: Colonial Social Accounting Cambridge University Press, 1953, pp. 115 and 116.

1) A. R. Prest and I. G. Stewart: The National Income of Nigeria. Her Majesty's Stationary Office, 1953, p. 4 
exchange economy are included in the calculation of the national income. In a pure subsistence economy, however, many productive activities take place within the family or the local community which are never reflected in market transactions. There is a wide variety of such non-market activities, which range from the production of primary food and other materials to the provision of all kinds of services such as hairdressing, undertaking amusement, recreation, sports, religious work, legal practice, medical services, training, finance services are provided by business concerns, but in a territory with a subsistence economy they are performed by the family and the community.

In developed countries (also called industrialized countries) it is easy to assess the value of the goods and services produced by the population, because there are few goods and services not offered on the market. In industrialized communities it is therefore customary to exclude all economic activities taking place inside the family circle.

In most primitive communities where women and children play an important part in the production of the family's food, the method of excluding these services in the calculation of the national income is therefore not applicable. In the words of P. Deane: "In a subsistence area where labour is normally unpaid and where labour is organised on a domestic basis, the bulk of the agricultural work falling on women, it is not possible to pursue an analogous policy".')

1) P. Deane: The Measurement of Colonial Incomes, Cambridge University Press, 1948, p. 24.
The fact that the subsistence output has to be considered in the evaluation of the national income of an underdeveloped territory is emphasized as follows by Deane: " ... if the concept of national income is to have any meaning when applied to a colonial economy it must include the self subsistence output of a native farmer ... Further, it should include the value of the wild foods, such as honey or game, or caterpillars - an important adjunct to the African's food supply and the value of huts and mats made by the producer for his family".') In this connection H. J. J. Reynders also maintains: "In order to obtain reasonably comparable figures, it is necessary to include in some way or other in the calculation of the national income in a subsistence economy those goods and services which are not bought and sold in the market". ${ }^{3}$ )

Without an intensive study of the national economy and of the agricultural communities in underdeveloped territories it is extremely difficult to gauge the productive activities outside the market sphere, and when the extent of these has eventually been assessed, the further problem of evaluation remains. In this connection Simon Kuznets says: "It is even

2) $P$. Deane: Measuring National Income in Colonial Territories, in Conference on Income and Wealth, Studies in Income and Wealth, Volume Eight, New York, 1946, p. 154.

3) H. J. J. Reynders: Nywerheidsontwikkeling in die Bantoegebiede van S.A., (Industrial Development in the Bantu areas of South Africa) D.Com., thesis, University of Pretoria, May 1955, p. 181. 
more difficult to assign values that would put these productive activities on a basis comparable with their counterparts in an industrialized market-bound economy".4)

In the national output of Bechuanaland Protectorate, three kinds of goods and services must be evaluated; viz.

(i) the hartered goods and services at actually known or estimated market prices;

(ii) the non-negotiable goods and services, e.g. food retained by the farmer for family consumption, at prices fetched by the coun. terparts of the products on the market; and (iii) those goods and services for which no direct counterpart exists, or in which trading is so limited or irregular that no reliahle impression of the market can be formed.

The supposition that the farmer's unsold output can be assessed at the prices of the sold output, is a reasonable criterion when the volume of unsold goods is so small that is can not influence the market. When the bartered goods form only a relatively small part of the total output such an assumption is not justified. When for example a rural community of a few hundred inhabitants produces 10,000 hags of maize, of which only 100 are sold, it is difficult to find an appropriate market price, because the unit price of 100 lags cannot simply be applied to the other 9,900 bags.

The alternative is to construct an artificial price system which takes cognizance of the actual values. Seeing that the local market is so small and the prices concerned are therefore no true reflection of ruling

4) S. Kuznets, Economic Change, Norton and Co., N.Y. 1953, p. 152. values, the said price system may be constructed by connecting local prices with those of the nearest big market. The obvious method is to approximate local prices to those of the central market, and to deduct the cost of transport from the central market price.

Omitting activities outside the market network in the calculation of the national income would leave the final result incom. plete. Kuznets says: "that one should try, by intensive field study, to get an inclusive picture of non-market productive activities in pre-industrial society is good advice, too obvious to be stressed... In the case of pre-industrial societies primary and semi-finished commodities flowing in. to ultimate consumption should be given the prices in industrial societies of the finished, fully manufactured products they enter, not of their exact crude or semifinished counterparts".')

In a subsistence economy where goods and services are produced by each indivi. dual for his own or his family's use, it is therefore essential to provide for such goods and services in the various tables of national income.

(b) Statistical Problems.

(i) Available sources of information for the Protectorate.

In the calculation of the national income and the drawing up of related accounts in a developed territory a start is normally made with the available publish. ed or other relatively accessible information which is usually compiled for these

1) Kuznets, op. cit., p. 155. 
purposes. In an underdeveloped territory, on the other hand, relatively little data exists, and a start must often be made with qualitative information which has been collected by social scientists and for other purposes.

In the case of Bechuanaland statistics for the said accounts are practically nonexistant, and in most cases calculations had to be based on information supplied by informants, published annual reports, minutes and publications of an anthropological nature.

The most important sources of information on this territory may be summarized as follows :

i) Published annual reports by the Administration.

a) Bechuanaland Protectorate, Colonial Annual Reports.

b) Bechuanaland Protectorate, Estimates of Revenue and Expenditure (includ. ing Development Schemes).

c) Bechuanaland Protectorate, Annual Reports of the Department of Geological Survey.

d) Bechuanaland Protectorate Government, Annual Reports of the Department of Veterinary Services.

e) Bechuanaland Protectorate, Annual Reports of the Department of Agricul. ture.

ii) Other publications by the Administration.

a) Bechuanaland Protectorate, Minutes of the European Advisory Council.

b) Bechuanaland Protectorate, Minutes of the African Advisory Council.

c) Bechuanaland Protectorate, Minutes of the Joint Advisory Council. d) Bechuanaland Protectorate, Census 1946.

iii) Sundry publications.

a) I. Schapera, Native Land Tenure in the Bechuanaland Protectorate, Lovedale Press, 1943.

b) I. Schapera, Migrant Labour and Tribal Life, Oxford University Press, 1947.

c) I. Schapera, A Handbook of Tswana Law and Custom. (Published for the International Institute of African Languages and Cultures by the Oxford University Press, 1938).

d) Commonwealth Relations Office, Report of a Mission to the Bechuanaland Protectorate to investigate the possibilities of economic development in the Western Kalahari, 1952, H.M.S.O., London, 1954.

e) Financial and Economic Position of the Bechuanaland Protectorate, Report of the Commission appointed by the Secretary of the State for Dominion Affairs, H.M.S.O., I.ondon, 1933.

iv) Unpublished information obtained from:

a) Secretariat of Bechuanaland Protectorate.

b) Offices of District Commissioners.

c) Office of the Director of Agriculture, Mahalapye.

\section{(2) Direct survey of the territory.}

The published sources of information mentioned above are insufficient for the projected calculations. Therefore recourse had to be had to the direct survey method. In January 1957 a visit was paid to the 
Protectorate and a survey was undertaken in each district (excluding Kgalagadi). This survey consisted of information obtained from the various District Commissioners, other officials, and businessmen, and of interviews with Bantu chiefs and tribe members.

Owing to the vast size of the territory, the poor roads and the scattered population it was impossible always to take representative samples. It is therefore realized that the information which has served as hasis for some of the calculations, was often very arbitrary.

Seeing that no complete agricultural census has so far been undertaken, and agriculture is really the most important economic activity in the Protectorate, extensive discussions were held with the then acting Director of Agriculture in Maha. lapye. With the aid of his knowledge of the territory, and some unpublished information which was made available, useful estimates ') of the agricultural production of the territory could be made. Most of the information concerning stockbreeding was obtained from the Director of Veteri. nary Services in Mafeking and veterinary surgeons within the Protectorate.

All information gathered refers to the

1) In cases where no output figures exist, consumption per family of flve was taken as a basis for the calculation of the total. A family census of the Bantu was made by the District Commissioner of Mochudi. According to him a family consists of five persons, including the head of the family, his wife or wives, and their children who are still living in the village, plus other adult persons who form part of the economic unit. year 1955. The most important reason for the choice of this year is the fact that (with some exceptions), the latest published annual reports (which were the most important sources of information) at the time of the survey were for 1955 .

\section{(3) Some other direct surveys.}

The computers of national income in underdeveloped territories have often in the past been faced with the problem of insufficient information, which has necessitated the conducting of direct surveys. Without mentioning them all here, it is nevertheless of interest to refer to similar surveys by Phyllis Deane in Northern Rhodesia and Nyassaland, Prest and Stewart in Nigeria, and the Tomlinson Commission who estimated the geographical income in the Bantu territories of South Africa.') In connection with the last survey mentioned, it may be pointed out that fieldwork was undertaken by agricultural economists and Bantologists. As a result of the time factor and the size of some of the Bantu reserves in the Union it was also impossible for these fieldworkers to make a complete survey, and sample studies had to suffice. Conditions in each reserve in the Union are homogeneous, and according to one of the agricultural economists who took part in the investigation, the result was completely satisfactory.

The Commission also made use of information about the district of Keiskama-

1) Union of South Africa. Commission for the socio-economic development of the Bantu areas within the Union of South Africa, Government Printer, Pretoria, 1955. Chap. 24. 
hoek which was made available by Prof. Hobart Houghton.

\section{(4) Reliability of estimates.}

Calculations of national income in un. derdeveloped territories are based on less reliable and accurate information than in developed countries. The relative inaccessibility of the remote districts (e.g. the Ggalagadi district); the shortage of trained personnel; the hostility of the Bantu in some cases, probably arising from a fear of taxation or religious taboos; the inability of the willing Bantu to co-operate successfully, are all examples of the obstacles encountered in the gathering of statistical data.

The margins of error can hardly be determined with any degree of accuracy. Therefore the relative size of the figures should rather be considered. Owing to the shortage of the necessary information ') some of the individual figures have little or no intrinsic value. The estimates will in time become more accurate as informa. tion is collected systematically.

1) With regard to information for the purpose of calculating national income in underdeveloped territories Deane says inter alia: "national income tables can be constructed for even the most backward territory and the most inadequate information... There seems little doubt that a series of comprehensive, up-to-date, and reasonably accurate national income est1mates could be made for any colony. Its practical value in planning the development of the uncharted economics... would be considerable". - "Measuring national Income in Colonial Territories," op. cit., pp. 168-169. (ii) The structure of the national output.

\section{(a) Agriculture.}

The economy of Bechuanaland Protectorate is an agricultural economy because almost the whole population depends for its existence on agricultural produce. Although the territory is by far the better suited to stock-breeding, agriculture is nevertheless practised on a small scale. The total contribution of agriculture to the geographical and national income of the territory in 1955 is estimated at $£ 3.6$ million. Of this sum about $80 \%$ came from stock-breeding, while the total value of the products of stock-breeding exported during the period 1947.1955 varied between $71 \%$ and $90 \%$ of the total local export.

The possibilities of agricultural development and therefore of agricultural production, are limited, not only by a low and uncertain rainfall, and unsatisfactory agricultural methods, but also by the cultural and social attitudes of the Bantu, according to which they are generally content merely to supply the wants of subsistence. The agricultural output is so low that a large percentage of the Bantu families are obliged to augment their insufficient income by working in the bordering territories, especially the Union of South Africa.

Owing to the communal feeling out of which social awareness grows, the individual will not starve as long as the commu. nity possesses the essential foodstuffs. This attitude does not foster greater exertion in order to increase individual output. The Bantu therefore rarely feel the desire to increase their income by means of increas- 


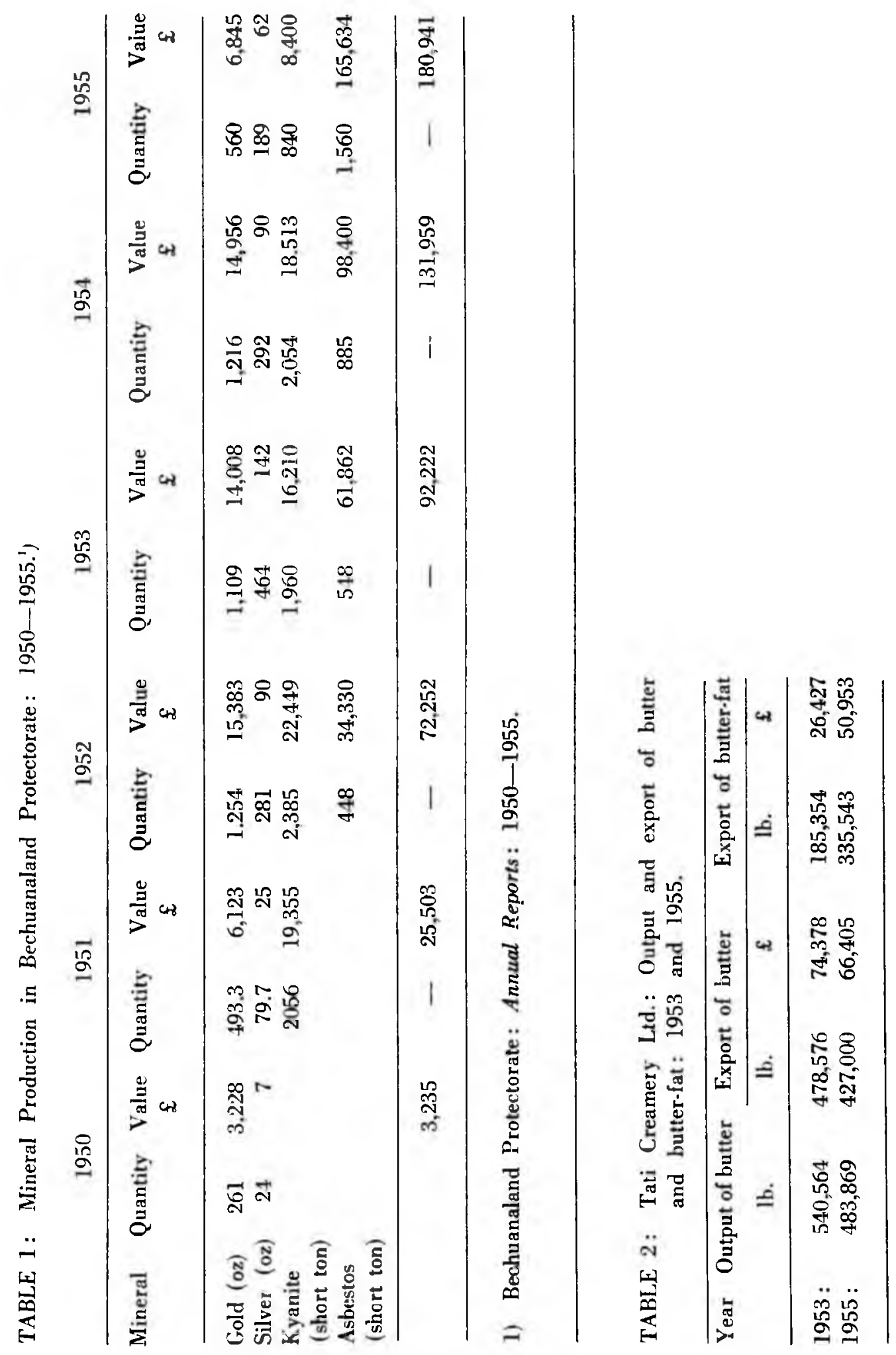


ed output in order to obtain other non. essential foodstuffs.

b) Primary, Secondary and Home Industries.

Despite the inherent obstacles of a sand-covered area and a shortage of water in many parts of the country, a large variety of mineral deposits has already been discovered. Table 1 indicates the development, extent and composition of the mineral industry. According to this table the mining of asbestos was the only important mining activity in the Protectorate up to 1955.

There are few important secondary industries in Bechuanaland, the only important ones are the Francistown Bonemeal Factory, The Tati Creamery and the Lobatsi Abattoir. The Francistown Bonemeal Factory which was opened on lst August 1954, produced about 700 tons of bonemeal during 1955 . Because of higher prices of bones in the Union the undertaking led a precarious existence so that Administration had to impose an export levy on bones. The Tati Creamery Ltd. also in Francistown, has been in existence since 1947. Its main activity consists in the purchase of cream and the manufacture of butter and butter-fat for the local and foreign markets. The output and export of butter and butter-fat of this creamery for 1953 and 1955 are shown in Table 2.

Table 2 shows that the output of the Tati Creamery is very much bigger than local consumption. According to an analysis of export statistics the Union is the most important market for this product.

The Lobatsi Abattoir was founded by the Colonial Development Corporation who met with strong opposition when they be- gan slaughtering cattle on their stock farms in the territory on the 20th September 1954. Since 4th October 1954 the public has been supplying the abattoir with cattle, since all exports on the hoof, except for those from Ngamiland through Kazungula to the north, have been prohibited.

The foundation of the Lobatsi abattoir may be regarded as one of the most important economic events in the Protectorate because it has promoted greater stability in the marketing of the cattle of the territory.

In Table 3 we have the extent of slaughterings of cattle for 1954 and 1955. TABLE 3 : Lobatsi Abattoir : Slaughtering of cattle for 1954 and 1955.

\begin{tabular}{lcc}
\hline Year & \multicolumn{2}{c}{ Carcases } \\
\cline { 2 - 3 } & \multicolumn{1}{c}{ lb. } & $£$ \\
\hline $\begin{array}{l}1954 \\
\text { (for } 3 \text { months) } \\
1955\end{array}$ & $2,668,318$ & 118,471 \\
\hline
\end{tabular}

Home industry played an important part in the traditional way of life of the Bantu. Not only did it provide him with most of his domestic and personal requirements, but is was also a means of artistic expression. Before he had made contact with Western civilization the Bantu was self-sufficient and could provide for his own material needs.

The most important industries which are today still practised to a greater or lesser extent may be divided into the following groups: i) fibre, grass, leaf and reedwork; ii) bone and horn work; iii) beadwork; iv) claywork and pottery; v) woodwork; vi) leatherwork and sundry home industries. 
Technique and production aids are simple and homemade implements are employed to a large extent. The extent of the activities of the Bantu in connection with the output of home industries is difficult to estimate. According to information gathered from Bantu individuals the value of the output of home industry articles per family unit of five is about $£ 3$ per year. But this is a very arbitrary estimate.

(c) Trade and transport.

For the purposes of calculating the contribution of trade to the national income of Bechuanaland Protectorate, trade is divided into two departments: i) the general dealers, both wholesale and retail, and ii) sundry services, such as refresh. ment, transport, recruiting, livestock agen. cies, garages and others.

Trade is conducted almost exclusively by Europeans. According to an analysis of general dealers' licences and turnovers in the territory about $74 \%, 15 \%$ and $11 \%$ of the general dealers' licences for 1955 were held respectively by Europeans, Bantu and Asiatics. The turnovers of the different races were respectively $86 \%$, $3 \%$ and $11 \%$ of the total turnover of about $£ 3$ million for that year.

The extent and nature of the most important import goods for the period 1951-1955 is summarized in Table 4.

Table 4 shows that staple foods, merchandise (including both consumers' and capital goods), and textiles amounted to between $72 \%$ and $85 \%$ of the total imports for the respective years. Import also show a tendency to increase. An analysis of the origin of imports reveals that the Union is the most important supplier to the territory, with Southern Rhodesia second. All imported merchandise reaches the consumer via European, Asiatic and Bantu traders who order directly from the manu. facturer or wholesaler outside the territory. These supplies are usually transported by rail to the nearest station and are taken from there to their destination by lorry. Some of the Bantu traders, especially im. porters, do not always honour their contracts. This attitude affects trade relations between foreign concerns and the Bantu traders in general, and retards the economic development of the territory.

The export trade consists almost exclusively of the export of primary commodities. This trade which in 1927/28 amounted to only $\mathfrak{3} 3$ million, had increased to $£ 2.8$ million in 1955 .

The most important components of the

TABLE 4: Extent and nature of most important import goods: 1950-1955.

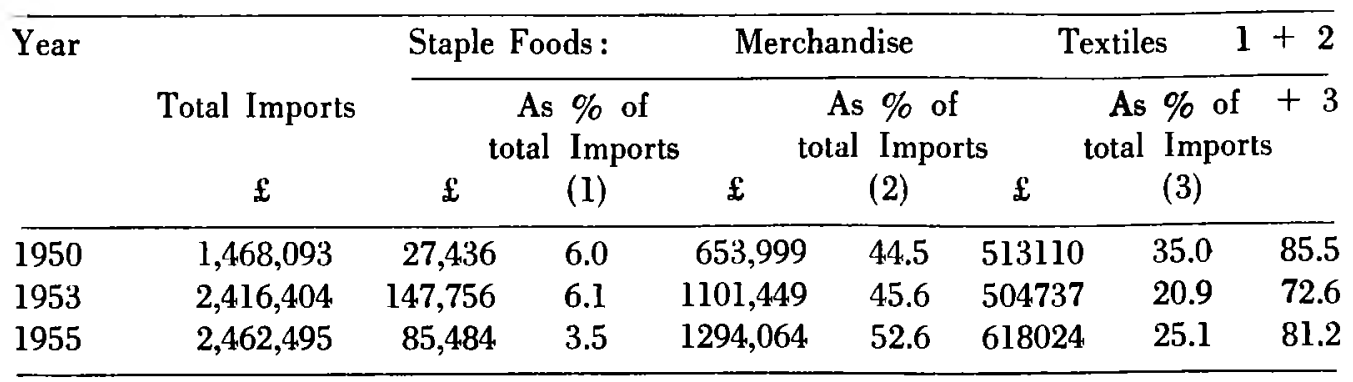


export trade are products of stock-breading (such as cattle carcases, hides, animal products) and minerals, which in 1955 amounted to about 72 per cent and 6 per cent, respectively of the total exports. An analysis of the destinations of the products shows that again the Union is not only the most important supplier to the territory, but is also by far the largest importer of Protectorate products.

Of sundry service institutions transport is the most important and for that reason it merits some consideration. Apart from the public railway which is far and above the most important means of transport in the territory, and to reference which has already been made, mention may also be made of the Native Recruiting Corporation (N.R.C. and the Witwatersrand Native Labour Association (W.N.L.A.). These two organizations transport only Bantu recruited for the Union gold mines. The road transport service of the N.R.C. is on a small scale in comparison with the air transport service of the W.N.L.A. This air service was begun in 1952 in Francistown. The contribution by transport to the geographical income of the territory for 1955 was estimated at about $\mathfrak{k} 3$ million.

\section{(d) Miscellaneous business.}

Under this heading a number of activities are discussed which have little or no connection with one another and which are relatively so unimportant that they do not merit separate treatment. For the sake of convenience the following matters are grouped together: (a) finance, (b) professions and services, (c) business undertakings of the Administration (the Post-Office), and (d) private building construction.
Finance generally includes: all kinds of banks, insurance companies, building societies, trust companies, stockbrokers, in -vestment companies, and estate agents. While all these bodies are usually found in industrialized countries, there are, with the exception of four branches of commercial banks with their head offices in the Union, no financial institutions in Bechuanaland.

Professions and services include private doctors, medical services and nursing, dentists, veterinary surgeons, accountants and auditors, actuaries, architects, quantity surveyors, surveyors, legal practitioners, engineers, journalists, writers, and others. This group therefore only includes persons who are not employed for a salery hy husinesses, the state or other institutions, but who practise these professions for their own profit. To these acknowled. ged professions may conveniently be added those services rendered by hairdresser, photographers, amusement vendors, religious workers, etc.

At the moment there are very few pro. fessional persons in the territory. There is especially a big shortage of doctors, because, except for the few government doctors and the individuals in the service of mission stations, there are very few other privately practising doctors and dentists. There are also a number of Bantu herbalists and witchdoctors in the territory. Seeing that there is no legal provision for the compulsory registration of this type of "profession". No information about their numbers or income is available.

Although there are a few licensed European hairdressers in the territory, this function is usually performed without 
remuneration among the different racial groups. Religious work is done by representatives of various churches. Funeral and other services are chiefly rendered on

a communal basis.

Up to 1956 the administration and control of the postal services in the Pro. tectorate were the responsibility of the Postmaster General of the Union of South Africa, subject to the authority of the Resident Commissioner, but in 1957 these services were taken over by the Administration of the Protectorate. The telegraph and telephone lines in the territory which connect the Union of South Africa with Rhodesia, were in 1955 mainly the pro. perty of Southern Rhodesia.

(e) Public authorities.

The public authorities of Bechuanaland may be divided into: i) the Admi. nistration under the personal supervision of the High Commissioner for the protectorates bordering on the Union, and, ii) the various tribal authorities which administer the Bantu territories according to a system of indirect rule. The estimated geographical income from the activities of the administration and tribal authorities is estimated for 1955 at about $£ 748,000$ and $\mathfrak{f} 112,00()$ respectively.

(f) Privade domestic service

Salaries and wages of the Bantu from household service on the farms as well as in the small towns, are estimated at $£ 27,000$. As far as could be ascertained there is no European in the service of a private household.

(g) Migrant labour.

Apart from the income accruing to the inhabitants mainly from activities within the territory it is also necessary to consider the importance of the income earned in neighbouring territories, especially in the Union, by means of migrant labour. This situation may be summarized as fol. lows : : i) About 95\% of the migrant labourers from Bechuanaland go to the Union; ii) in 1955 more than $5 \%$ of the total Bantu population of the Protectorate were living in the Union; iii) migrant labourers in 1955 received an estimated total income of about $£ 2,500,000$ (in cash and in kind) in the Union; iv) more than $60 \%$ of their total income in the Union came from goldmining; v) migrant labou.

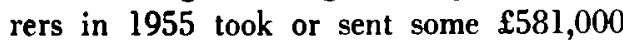
in goods and cash to the Protectorate, this amount consisting of $\mathfrak{1 2 9 5 , 0 0 0}$ in goods and $£ 286,000$ in cash; vi) after subtraction of taxes the Bantu population in the Protectorate have derived from migrant labour a henefit of more than $£ 258,000$, or about \$3.10. per family in cash, and al. most $\mathfrak{A} 4$ per family in the form of goods; vii) by far the larger part of the total income of migrant labourers is spent in the country where they are employed.

(iii) The geographical and natonal income of the territory.')

In Table 5 the geographical and natio. nal income of the territory is shown for each sector on a racial basis. From this it appears that: (a) the geographical and national incomes amount to $£ 9.8$ million and $\mathbf{2 7 . 1}$ million respectively; (b) the agri. cultural sector makes the most important

1) In the absence of any information on the now of capital it is impossible to draw up the balance of payments for the territory. 


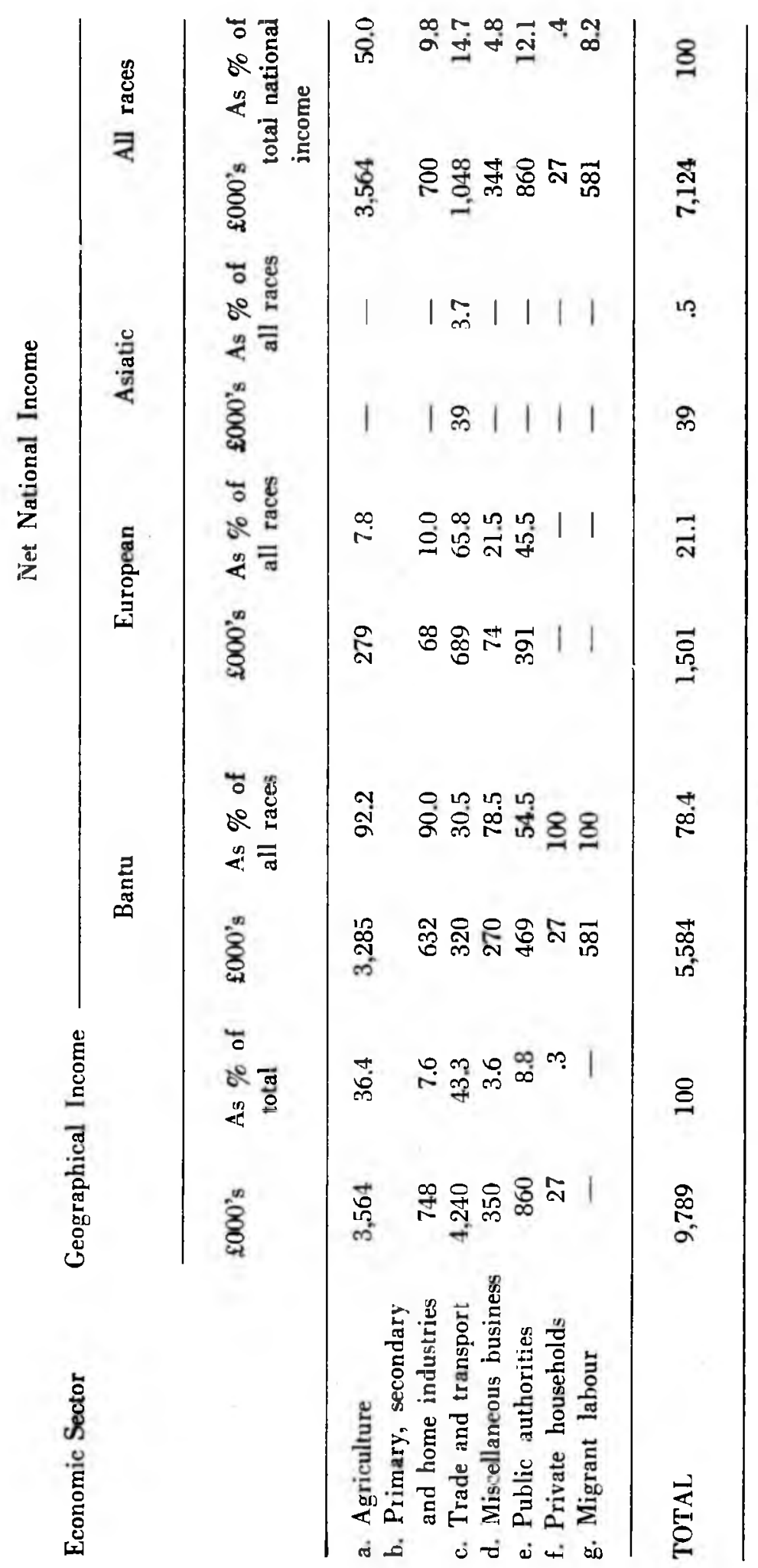


contribution to the national income; (c) the shares of the national income of the Bantu and the Europeans who constitute respectively about 99 per cent, and 1 per cent of the population, are 78 per cent and 21 per cent respectively; (d) the Europeans derive most of their income from trade; (e) migrant labour makes an im. portant contribution to the national income of the territory.

In Table 6 the national income per capita for Europeans and Bantu is estimated.

Table 6: Bechuanaland Protectorate: Estimated national income per capita according to race: 1955.

\begin{tabular}{|c|c|c|c|}
\hline \multirow[b]{2}{*}{ 迅 } & $\begin{array}{l}\text { Estimated } \\
\text { Population') }\end{array}$ & \multicolumn{2}{|c|}{$\begin{array}{c}\text { Estimated } \\
\text { national Income }\end{array}$} \\
\hline & 总 & 岁 & 焉 \\
\hline Bantu & $\left.373,385^{2}\right)$ & 99.3 & 5,584 \\
\hline Europeans & 2,659 & .7 & 1,501 \\
\hline Total & 376,044 & 100.0 & $7,08518.84$ \\
\hline
\end{tabular}

These figures show that: (a) the estimated total national income per capita for Europeans and Bantu for 1955 was estimated at $£ 564$ and $£ 15$ respectively; (b) the estimated national income for the territory amounts to about $£ 19$ per capita.

1) Excluding Asiatics.

2) Coloureds included.

\section{Conclusion.}

From the foregoing it is clear that cattle farming is by far the most important activity in the Protectorate. In 1955 it contributed more than $40 \%$ of the na. tional income of the territory. The lack of a larger variety of output is therefore one of the biggest defects in the national economy of the territory. As a result the export services of the territory, which must pay for the imports, are extremely vulnerable. A large increase in the value of the export of cattle on the hoof will benefit almost the whole population. It is therefore essential that special attention be paid to greater differentiation of products.

Although the income per capita in the territory is low in comparison with Western countries, the economy may not be regarded as stagnant, and it must be re. membered that the subsistence economy is gradually being replaced by a monetary and market economy.

In connection with the composition of the geographical and national income of Bechuanaland Protectorate it must in conclusion be pointed out that the figures are only an indication of the relative importance of each sector. Phyllis Deane's remark about her calculation of the national income of Northern Rhodesia is also true of Bechuanaland, viz.:"Most of the individual figures have little or no intrinsic value because the information is altogether too scanty for close estimates. They are, however, essential elements in the picture of the economy ....... suggested by all available evidence." ) P.U. vir C.H.O.
D. P. Erasmus.

1) P. Deane: "Measuring National Income in Colonial Territories". op. cit., p. 168. 